\title{
Feeding value of protein-rich peas for weaned piglets
}

\author{
J. P. BOUARD (1), J. CASTAING ( $\left.{ }^{2}\right)$, J. FEKETE (1) \\ M. LEUILLET ( $\left.{ }^{1}\right)$, F. MERLE $\left({ }^{3}\right)$ \\ (1) I.T.C.F., 8, avenue du Président-Wilson, 75116 (Paris) \\ ( $\left.{ }^{2}\right)$ A.G.P.M., I, place de Lestapis, 64000 Pau (France) \\ (3) C.C.P.A., Z.A., I2, rue des Beaux-Soleils, 95520 Osny (France)
}

Three coordinated trials were made on the utilization of protein rich peas (variety Frimas) in weaned piglets. The incorporation levels were o, I 5,30 and $45 \mathrm{p}$. I oo depending on the place of the experiment. The dams of the piglets came from " minimal disease " Large White herds. Piglets were weaned at 26 days, on an average, then kept in a special rearing house in flat deck pens. After an adaptation period of about twelve days, they were fed experimental diets during 4 to 5 weeks.

The results of these trials were grouped together and concerned 858 piglets with a mean live weight of $8.5 \mathrm{~kg}$ at the beginning of the experiment and $25 \mathrm{~kg}$ at the end.

The performance of piglets fed with $3^{\circ}$ to $45 \mathrm{p}$. I oo peas were reduced as compared to the controls. The appetite of piglets was first affected, their feed intake reaching 97 and $83 \mathrm{p}$. I oo, respectively of that of the controls. Thereafter, the growth rates decreased almost linearly. The feed conversion ratios varied from 105.5 to $107.7 \mathrm{p}$. I 00 as compared with diets without peas. Thus, a lower intake was companied by a lower feed efficiency.

The performance of piglets fed with diets including I 5 p. I oo peas were very close to those of the controls. The slightly increased feed intake (3 times/3) led to a slight improvement in growth and feed efficiency (2 times/3).

This incorporation level must therefore be considered as a maximum one in 2 nd age feeds offered from $8 / 9 \mathrm{~kg}$ live weight.

\section{Utilization of peas in early weaned piglet diets. Influence of the type of cereal}

\author{
G. BERTRAND (1), J. M. PEREZ ${ }^{2}$ ) et P. QUÉMERE ( $\left.{ }^{1}\right)$ \\ (1) S.E.R.E.P., Institut Supérieur Agricole, 60026 Beauvais (France) \\ (2) I.N.R.A., Station de Recherches sur l'Elevage des Porcs \\ $7835^{\circ}$ Jouy-en-Josas (France)
}

Recent French studies showed that incorporation of I 5 p. xoo peas combined with three cereals (barley, wheat, maize) into 2 nd age diets led to favourable results between 9 and $26 \mathrm{~kg}$ live weight, while use of higher levels reduced the performance.

Two series of trials were made just after weaning ( 3 to 4 weeks of age) in piglets of $5^{-7} \mathbf{~ k g}$ live weight distributed into three weight classes (heavy, mean, light) in order to study the influence of incorporating peas into diets including a single cereal:

- $20 \mathrm{p}$. roo peas added to a diet based on maize (frst topic, 4 trials, 96 piglets $/$ trial);

- 30 p. roo peas added to a diet based on wheat or maize (2nd topic, 3 trials, Io8 or 96 piglets / trial).

The diets exhibited the same protein and energy characteristics (lysine, sulphur amino acids, digestible Energy). In both treatments, the results showed a very high repeatability.

The results of the first series of trials ( 384 piglets) showed that incorporation of 20 p. I0o peas into a diet based on maize:

- reduced piglet feed intake ( -9 p. Ioo) and growth rate ( - ro p. I oo) especially during the Ist age period ( 3 to 6 weeks) and in heavy piglets $(-37 \mathrm{p}$. Ioo);

- little affected the feed conversion ratio on the whole period, but increased it considerably just after weaning $(+32 \mathrm{p}$. Ioo) particularly in heavy piglets $(+54$ p. roo). 